\title{
Future therapy of portal hypertension in liver cirrhosis - a guess
}

\section{Tilman Sauerbruch* and Jonel Trebicka}

\author{
Address: Department of Internal Medicine I, University of Bonn, Sigmund-Freud-Strasse 25, 53125 Bonn, Germany \\ *Corresponding author: Tilman Sauerbruch (tilman.sauerbruch@ukb.uni-bonn.de) \\ Fl000Prime Reports 2014, 6:95 (doi:10.12703/P6-95) \\ All Fl000Prime Reports articles are distributed under the terms of the Creative Commons Attribution-Non Commercial License \\ (http://creativecommons.org/licenses/by-nc/3.0/legalcode), which permits non-commercial use, distribution, and reproduction in any medium, \\ provided the original work is properly cited. \\ The electronic version of this article is the complete one and can be found at: http://fl000.com/prime/reports/m/6/95
}

\begin{abstract}
In patients with chronic liver disease, portal hypertension is driven by progressive fibrosis and intrahepatic vasoconstriction. Interruption of the initiating and perpetuating etiology-mostly leading to necroinflammation-is possible for several underlying causes, such as autoimmune hepatitis, hepatitis B virus (HBV) infection, and most recently hepatitis $\mathrm{C}$ virus (HCV) infection. Thus, in the long run, lifestylerelated liver damage due to chronic alcoholism or morbid obesity will remain the main factor leading to portal hypertension. Both causes are probably more easily countered by socioeconomic measures than by individual approaches. If chronic liver injury supporting fibrogenesis and portal hypertension cannot be interrupted, a wide variety of tools are available to modulate and reduce intrahepatic resistance and therewith portal hypertension. Many of these have been evaluated in animal models. Also, some wellestablished drugs, which are used in humans for other indications (for example, statins), are promising if applied early and concomitantly to standard therapy. In the future, more individually tailored strategies must also be considered in line with the spectrum of portal hypertensive complications and risk factors defined by high-throughput analysis of the patient's genome, transcriptome, metabolome, or microbiome.
\end{abstract}

\section{Introduction}

Portal hypertension is not a disease in itself. Rather, it is an indication of an illness, caused mostly by chronic lesions of the liver because of distinct causes, such as viral infection, chronic alcoholism, or metabolic disorders. Other reasons include splanchnic vascular diseases (for example, obstruction of the portal or the hepatic veins). This article focuses on liver disease leading to portal hypertension defined as a pressure in the portal vein exceeding the vena cava pressure by more than $5 \mathrm{~mm} \mathrm{Hg}$ [1].

The primary cause is an increase in the resistance to drainage of portal venous blood through the liver to the right atrium. This leads to a vasodilation of splanchnic veins, which-with increasing portal pressure-results in de novo formation of collaterals to bypass the liver. Major consequences of this are hyperdynamic circulatory changes, not only in the splanchnic vascular bed but also in the lungs and in the arterial cardiovascular compartment with counteractions comprising the kidneys, the heart, and the endocrine system $[2,3]$.
Sequelae are complications such as ascites, intestinal bleeding, or hepatic encephalopathy. In the past, most efforts concentrated on treatment and prevention of these complications. We believe that, in the future, research will lead to a change of paradigms - at least in Western countries-since the infectious causes of chronic liver disease will fade while metabolic and toxic causes will remain. It can be assumed that, with increased life expectancy, adults in Western Europe will be more burdened by cardiovascular disease, cancer, or dementia syndromes than by complications of portal hypertension. However, in the ranking of leading causes of years of life lost, these complications range between fourth place (Central Europe) and ninth place (in other high-income countries) at the moment [4]. Knowledge of individual reactions to exogenous exposure, toxins, environmental challenges, drugs, or inflammatory stimuli will increase. This will result in improved prevention and in definition of at-risk patients and of those who will benefit from specific measures. Thus, better knowledge of the pathophysiology of the mechanisms which augment intrahepatic resistance 
may allow the development of methods to specifically target cells within the liver which are the active players in fibrogenesis, cell contraction, and vascular remodeling. In this situation, it must always be kept in mind that drugs or modulators, acting within the liver, may have contrary effects on the splanchnic and systemic vascular compartment outside the liver. This review attempts to make some predictions regarding future therapy of portal hypertension with particular emphasis on the catalyst, namely an increase in intrahepatic resistance.

\section{Decrease of viral associated liver cirrhosis}

Worldwide, 350 to 400 million people are assumed to suffer from chronic HBV infection and 160 million from HCV infection [5,6]. Although the possibilities of vaccination against $\mathrm{HBV}$ and effective drugs to suppress HBV replication have existed for decades, the development of treatment of chronic HCV infection, especially for patients with advanced fibrosis or cirrhosis, has remained stagnant for some time. However, the design of direct-acting antiviral agents, including inhibitors of the formation of viral structural proteins, such as NS3/4A protease, NS5B polymerase, and non-structural protein NS5A, with minimal side effects and high efficacy [7], has recently initiated extremely promising trials showing that, even in patients with liver cirrhosis, viral replication can be interrupted in more than 9 out of 10 patients with negligible side effects and a recurrence rate of below 3\% [8-10], and it has been shown that interruption (HCV) or suppression (HBV) of viremia prevents complications caused by portal hypertension, even in cases of stage 3 or 4 fibrosis [11-13]. Future therapy thus will no longer have to concentrate on viral-associated portal hypertension, at least in the long term. For example, calculations based on the current prevalence of HCV infection and presumptions of an optimal future treatment and screening allow the conclusion that HCV-associated cirrhosis, as a cause of portal hypertension, will decrease from around 35,000 to 5500 (2030) in Germany, from 4500 to 500 in Sweden, from 35,000 to 1000 in France, and from 11,000 to 2000 in England [14]. The prevention of portal hypertension in these situations is challenged mostly by economics (costs of screening and new drugs), education, and adherence (willingness to get vaccinated, screened, and treated) [10].

\section{Alcohol and portal hypertension}

Per-capita alcohol consumption is strongly correlated with liver cirrhosis [15]. According to older trials, alcoholic liver disease as the cause of portal hypertension shows a very strong East-to-West gradient with increasing incidence in the eastern parts of Europe [16].
It can be assumed that the relative proportion will increase. However, it is difficult to speculate whether the absolute number of patients with chronic alcoholic liver disease will rise or decline. A very recent analysis from Denmark clearly shows that increasing the tax on alcoholic beverages, raising the minimum legal drinking age, and banning advertisements are more cost-effective measures than individual interventions $[17,18]$. Obviously, the introduction of such measures is a political issue. As there is no reliable evidence at the moment that chronic alcohol intake will decrease comprehensively, further information and research are required to demonstrate how alcohol intake, in particular, leads to an increase in intrahepatic resistance. To date, acetaldehyde-induced toxic effects, generation of reactive oxygen species, direct or indirect stimulation of hepatic stellate cells (HSCs) by metabolites, or inflammatory pathways are debated. Also, changes in the microbiota together with a leaky intestinal barrier are increasingly discussed as initiators of hepatic inflammation in patients with alcohol abuse [19].

In the absence of good animal models to recapitulate the human course of alcoholic liver disease [20,21], it is of utmost importance to improve the understanding of the pathogenesis directly in humans, including the individual response to the toxins, personal traits at risk, and respective pathways involved. Although this knowledge may lead to a slightly better treatment of portal hypertension, it appears a rather complex, if not impossible, approach for primary prevention of portal hypertension in a patient unable to abstain from alcohol abuse.

\section{Non-alcoholic fatty liver disease and portal hypertension}

The prevalence of non-alcoholic fatty liver disease (NAFLD), defined as more than 5\% hepatocytes with fatty infiltration, is believed to range between $10 \%$ and $20 \%$ in Western Europe [22-24]. NAFLD carries a 5\% risk for development of cirrhosis within a mean period of 8 years. Probably less than $1 \%$ of the patients die because of portal hypertension (variceal hemorrhage) [25]. However, in the US, one quarter of the patients with NAFLD show signs of portal hypertension as assessed by varices, encephalopathy, splenomegaly, or ascites [26]. Approximately $5 \%$ to $15 \%$ of patients have inflammatory changes together with hepatic steatosis (non-alcoholic steatohepatitis, or NASH), which are strongly linked to insulin resistance and type II diabetes mellitus [22,23]. In these patients, the risk of developing progressive fibrosis and cirrhosis may increase to $40 \%$ over a period of nearly 5 years, and around 5\% will develop complications of end-stage liver disease [27-30]. Of the patients 
with NASH-associated cirrhosis, one third may develop bleeding or ascites (or both) during the following 10 to 15 years [27-30]. However, in patients with fatty liver disease on the whole, morbidity and mortality are determined more by cardiovascular complications and malignancy than by hepatic decompensation [31]. Thus, it is important to identify patients in whom pre-primary or primary prophylaxis of portal hypertension may be justified. Patatin-like phospholipase domain-containing protein 3 (PNPLA3) polymorphisms may be used as a marker of more rapid fibrogenesis [32] with or without concomitant necroinflammation of the liver. For these high-risk patients, interruption or modulation of this process leading to portal hypertension and its complications may provide a potential approach. A high risk of developing liver disease is also present in patients who have central obesity and insulin resistance [33], ultrasound signs of high fat content in the liver, increased NAFLD/fibrosis scores (Fibrotest, NashTest, SteatoTest, and so on), already increased fibroscan values, and/or histological signs of steatohepatitis [34]. In these patients, dietary and physical activity interventions together with behavioral strategies may decrease the NASH activity score if weight loss surpasses 10\% [35]. Presumably, this can be achieved in only a limited number of patients, whereas bariatric surgery is significantly more effective with respect to weight loss and improvement of hepatic steatosis [36]. However, surgical treatment has to be performed prior to occurrence of portal hypertension since otherwise surgery increases postoperative mortality up to 20-fold [37]. Furthermore, alcohol abuse, with its potential for liver damage, may increase after gastric bypass surgery [38]. More recent findings show that bariatric surgery impact is based on considerable changes of gut hormones and adipocytokines, which shift from a pro-inflammatory to an antiinflammatory state $[39,40]$. These alterations have beneficial effects on hepatic necroinflammation and reduce appetite. Thus, bariatric surgery will play a role in only the very early pre-primary prophylaxis of portal hypertension as it is much too dangerous at a later stage. In this situation, prevention of hepatic disease with portal hypertension may be more easily achieved by a less invasive modulation of adipokines and gut hormones, if available. Since many of these patients present with hypertension and other signs of cardiovascular disease, the concomitant effects of angiotensin II type I receptor (AT1R) blockade or statins on the liver should also be further investigated to prevent fibrosis leading to portal hypertension and its complications, as suggested by animal models [41-47]. Here, controlled human studies with clear hepatic endpoints are required in the future.

\section{Modulation of pathways that increase intrahepatic resistance}

Chronic injury of the liver-whether due to infections, toxins, cholestasis, or metabolic or autoimmune disease-induces an inflammatory cascade leading to activation of HSCs, which reside in the space of Disse, to hepatic myofibroblasts, the key cells in the process of fibrogenesis. These cells also have contractile properties; they proliferate and are involved in a complex crosstalk with immune cells [48-50]. When activated, they express receptors which lead to an enhanced response to transforming growth factor-beta (TGF $\beta$ ), platelet-derived growth factor (PDGF), angiotensin II, or chemokines. These phenomena together with extracellular matrix proteins and integrins are involved in the modulation of the profibrotic activity of the myofibroblasts [51-53]. In these cells, receptor-mediated intracellular signaling involves small GTPases (for example, RhoA), intracellular kinases (Rho-kinase system, Erk, and JAK 2), and Ca-dependent pathways [41,42,54-58]. Activation of different nuclear receptors is also involved in the process of HSC activation [59]. Macrophages, resident (Kupffer cells) or recruited from monocytes, are important players, which initiate and perpetuate fibrogenesis, cell contraction, and angiogenesis [60,61].

Many approaches to modulate or interrupt these different processes have been investigated. Blockade of AT1R and the induced intracellular pathways with a special focus on myofibroblasts reduces intrahepatic resistance and portal pressure as shown by systemic application of Rho-kinase inhibitors or other approaches targeting Rho-kinase activity [41,57,62-65]. The problem of systemic side effects can be solved, at least in the animal model, by specifically targeting the intrahepatic non-parenchymal cells using carriers, which aim at activated HSCs and deliver AT1R blockers, Rho-kinase inhibitors, or interferon-gamma specifically to these cells [66-70]. Furthermore, macrophages are pivotal for HSC activation and upregulation of intrahepatic vasoconstrictors; therefore, they represent a suitable target to blunt progression of fibrosis and portal hypertension [71,72]. Several research teams have attempted to paralyze recruitment, activation, or effector secretion of these cells. Thus, inhibitors of leukotriene (montelukast), $\mathrm{Na}^{+} / \mathrm{H}^{+}$-channel blockers (amiloride), and cannabinoid receptors (CBRs) targeting the intrahepatic macrophages attenuate portal pressure by the reduction of hepatic resistance [73-76].

Interestingly, macrophage activation within the liver persists after reduction of intrahepatic resistance by using transjugular intrahepatic porto-systemic shunt (TIPS) 
[77-79], suggesting that the inflammatory component should be considered in the treatment of portal hypertension in cirrhotic patients as well, even after successful decrease of portal pressure.

It has been known for quite some time that there is an imbalance in favor of vasoconstrictors versus vasodilators within the liver. Thus, increased levels of endothelin, angiotensin II, norepinephrine, and other vasoconstrictors cannot be compensated by vasodilators such as nitric oxide (NO), the formation of which is reduced in the cirrhotic liver $[48,80]$. Increase of intrahepatic NO formation clearly decreases intrahepatic resistance and portal hypertension. This can be achieved by delivering NO to the liver $[81,82]$ (even though disappointing in humans), by modulating NO synthase [83], and interestingly by increasing the $\mathrm{NO}$ availability by using statins or obeticholic acid $[41,57,84-86]$.

It is difficult to predict which of these approaches, if any, will reach the stage of evidence-based clinical routine in humans, since any such treatment is incomplete and much more complex than interruption of the main cause which initiates and perpetuates liver disease. Established substances, proven in the treatment of other indications for many years, are the primary candidates and include statins, AT-1 receptor blockers, and farnesoid-X receptor (FXR) agonists [41,57,84-86]. These substances not only reduce intrahepatic resistance to a certain, albeit minor, degree (around 10\% to 20\%) but-at least in the animal model-also blunt fibrogenesis. Additionally, statins improve endothelial dysfunction and blunt a general inflammatory response, both present in patients with liver cirrhosis $[84,86]$. Therefore, early administration of these substances should be tested mainly in those patients in whom interruption of liver injury leading to liver fibrosis and portal hypertension has failed. This could apply to patients with autoimmune chronic liver disease who respond incompletely to ursodesoxycholic acid (UDC) in primary biliary cirrhosis (PBC), patients with primary sclerosing cholangitis (PSC), patients unable to abstain from alcohol, and patients with latestage NAFLD or genetic liver disease.

\section{Renin-angiotensin system and portal hypertension}

The systemic renin-angiotensin system (RAS) plays a major role in the regulation of the blood pressure and aldosterone secretion, both of which are deranged in patients with liver cirrhosis and portal hypertension. High renin levels in serum can be found in patients with compensated liver cirrhosis [87] and increase considerably with decompensation of liver cirrhosis [88]. In addition, local RAS activation in different tissues, especially the liver and kidney, occurs [89,90]. One major reason for systemic activation of RAS (and secretion of other vasoconstrictors) is the response to a decrease of the intrathoracic effective arterial blood volume caused by splanchnic pooling $[2,91]$. Formation of the main effectors (angiotensin II and aldosterone) leads to ascites via renal sodium retention on the one hand and portal hypertension via increase of intrahepatic resistance following activation of vascular smooth muscle cells and HSCs/myofibroblasts on the other. It has been repeatedly shown that myofibroblasts express AT1 receptors $[58,92,93]$. This explains why blockade of AT1 receptors decreases intrahepatic resistance and blunts fibrogenesis, especially in animal models $[93,94]$. This is in agreement with AT1 receptorinduced intracellular downstream signaling [58]. Accordingly, AT1 knockout mice show less fibrosis, whereas genetic overexpression of RAS or long-term angiotensin II infusion enhances fibrosis and portal pressure (Research group J Trebicka and T Sauerbruch, unpublished data) in rodents [94-96]. Although upregulation of intrahepatic RAS has also been demonstrated in human cirrhotic tissue, clinical trials showed only a trend toward reduction of portal pressure and fibrosis compared with placebo $[97,98]$ after earlier very promising reports [99]. In some trials, systemic application was burdened by hemodynamic side effects [100]. This can be explained by deleterious effects of AT1 receptor blockade in patients with decompensated cirrhosis in whom high activation of RAS is necessary to maintain adequate blood pressure [3]. Thus, RAS blockade to modulate fibrosis and lower portal hypertension probably requires early and long-term treatment with low dosages $[63,101]$, at a time when patients have compensated disease, or require specific targeting of intrahepatic myofibroblasts. However, the necessity for further drug development and subsequent phase I/II trials hampers application of the latter approach in the near future. Systemic application of low doses may be the most promising $[63,101,102]$. There are indications that-at least in patients with low renin values-sodium retention of the kidney may also be positively influenced by AT1 receptor blockade $[63,101,102]$. A future therapy of portal hypertension by chronic application of AT1 receptor blockers is reasonable only in patients in whom interruption of the baseline cause of chronic liver cirrhosis cannot be achieved or only partially. Treatment may be combined with propranolol [103] or statins as in cardiovascular disease [86].

Blockade of the AT1 receptor leads to a rebound increase of renin [100] and angiotensin II, which is not only the substrate for cleavage to angiotensin I via angiotensinconverting enzyme (ACE) but also the precursor for 
the formation of angiotensin (1-7) via ACE2 and ACE $[97,104]$. More recent findings show that angiotensin (1-7) induces vasodilation and blunts fibrosis via stimulation of the Mas-receptor, counteracting deleterious intrahepatic effects in chronic liver disease [97]. At the same time, Mas-receptor stimulation augments extrahepatic splanchnic vasodilation [104], which may increase portal tributary blood flow and portal pressure. This underlines how complex and double-edged manipulation of the RAS in chronic liver cirrhosis can be.

\section{Intestine and portal hypertension}

A complex interaction exists in humans and other mammals between microbes that colonize different organs by a factor of 10 compared with the eukaryotic cells of their own body [105]. The intestinal tract is by far the most heavily colonized compartment. If the composition of the intestinal microorganisms or the intestinal barrier together with its immune system or both are deranged, the liver is the first organ to encounter microbial products in the sinusoidal delta entered via the portal vein. Such pathogen-associated molecular patterns (PAMPs) or other small molecules may liberate inflammatory cytokines or reactive oxygen species (ROS) via sensing proteins such as inflammasomes [106,107] or Toll-like receptors (TLRs) and elicit intrahepatic vasoconstriction as well as HSC activation [108]. Changes of the intestinal microbiome are believed to contribute decisively to the generation of hepatic inflammation and fibrogenesis [109], especially in overweight patients and patients with alcohol abuse and hepatic steatosis. Currently, more statistical, rather than functional, associations have been generated with the help of the rapidly growing options of high-throughput techniques [110]. With better understanding of how and why gut microbiota change and which key molecules perpetuate intrahepatic cell activation and vasoconstriction, specific interventions in the gutliver axis may become a future tool for modulation of portal pressure. Thus, it has been shown that intake of rifaximin, a poorly absorbed antibiotic with broadspectrum antimicrobial activity, reduces systemic lipopolysaccharide (LPS) levels (LPS leads to induction of tumor necrosis factor production via TLR4), decreases portal pressure, and improves systemic hemodynamics [111-113]. However, the other way around, portal decompression using TIPS does not impede the inflammatory influx and its effect on mortality $[78,79]$. This may be one explanation for the minor impact of shunt procedures on survival $[114,115]$.

The enterohepatic circulation of the bile acids and its influence on portal pressure, the gut, and the respective immune system have been underestimated for a long time. However, now the potential therapeutic role of FXR agonists in blunting bacterial translocation has been demonstrated in recent experimental studies [116-118].

\section{Shunts}

Shunts were introduced for prevention of variceal bleeding in the 1960s through open surgery $[119,120]$ and since the early 1990s through a TIPS, creating a direct bridge between an intrahepatic branch of the portal vein and the hepatic vein $[121,122]$. It has been shown in numerous controlled trials that shunts decrease portal hypertension more effectively than any other method and that they guarantee the best prophylaxis from variceal bleeding. Furthermore, excellent studies have shown that TIPS is the optimum approach to blunt RAS activation and treat refractory ascites by improving renal sodium excretion $[122,123]$. Yet despite these beneficial effects, it is still doubtful whether elective TIPS prolongs survival $[114,115]$. In fact, reduction of portal venous perfusion of the liver may even deteriorate liver function and shorten time to liver failure in patients with marginal liver function. Interestingly, signs of intrahepatic inflammatory response persist after TIPS as mentioned above [77-79], suggesting that the mere interruption of portal hypertension improves disease-associated cardiovascular changes but not the chronic inflammatory response found in liver cirrhosis. Although elective or rescue shunts for variceal bleeding have not been shown to convincingly improve survival, there is new evidence from small controlled trials that very early shunting-within less than 2 days after a variceal bleeding episode-using TIPS [124-126] prolongs long-term survival compared with standard non-shunt therapy in high-risk patients. Although they lack some basal requirements for clinical trials, data from one very experienced center suggest that an immediate open surgical side-to-side shunt is superior to endoscopic hemostasis and even to TIPS with respect to long-term survival and rebleeding [127]. One may hypothesize from these few studies that there is a subgroup of patients with portal hypertension in whom bleeding is the prime problem and who are therefore candidates for early shunt treatment. Future management will need more input to define these patients.

\section{Infection and portal hypertension}

Acute infections worsen portal hypertension in patients with liver cirrhosis and may induce bleeding $[128,129]$. In contrast, variceal hemorrhage itself is less often a precipitating event for acute-on-chronic liver failure [130]. Nevertheless, if patients bleed because of portal hypertension, antibiotic therapy is paramount and one of the most important steps to prevent death $[131,132]$.

In regard to primary prophylaxis of complications due to portal hypertension, more information is required on 
the individual response to infections [133-135], especially to stimuli coming from the gut in order to investigate whether antibiotics can reduce portal pressure and prevent bleeding in selected patients [113].

\section{Adrenergic system and nitric oxide}

There exists the paradox of an enhanced vasoconstrictive response within the liver and a decrease outside the liver. Both phenomena contribute to the pathogenesis of portal hypertension and the generalized vascular dysfunction in patients with liver cirrhosis [136,137]. The interconnection between $\beta$-adrenoceptors and NO, which is of particular importance for the alterations outside the liver, is beyond the scope of this review. Within the liver the progression of disease upregulates $\beta 3$-adrenoceptors, which mediate relaxation of contractile cells, and therefore might offer a suitable target to decrease resistance using selective agonists [138]-similarly to the abovementioned enhancement of intrahepatic NO formation.

Outside the liver, non-selective $\beta$-blockers, introduced more than three decades ago for prevention of variceal rebleeding, have held a paramount role in the prophylaxis of variceal bleeding [139-141]. According to current knowledge, they reduce portal pressure by lowering portal tributary blood flow $[140,141]$. Carvedilol, a nonselective $\beta$-blocker with intrinsic alpha-1-adrenergic activity, may replace propranolol in the future as suggested by randomized trials on prophylaxis of first bleeding and one trial [142], which compared the hemodynamic response of the two substances [143].

\section{Personalized treatment of portal hypertension}

A common catchword for future treatment approaches in medicine is personalized treatment. In regard to portal hypertension and liver cirrhosis, several aspects have to be taken into consideration: etiology of liver disease and different natural outcomes, which determine time to liver failure or a variety of complications (for example, primary bleeding, ascites, or hepatocellular carcinoma) or both. All of these require different interventions. Thus, patients presenting with high renal sodium retention, ascites, and bleeding may profit more from TIPS than patients presenting only with bleeding, whereas patients who do not show adequate reduction of hepatic venous pressure gradient to $\beta$-blockers or who have severe ascites or spontaneous bacterial peritonitis may be poor candidates for primary prophylaxis of variceal bleeding with propranolol [144-146].

In the future, genetic, metabolomics, or proteomic information, as well as an integration of all of these, may help to better assign patients to the right therapies. The genetic information may include genes that make patients prone to alcoholism as well as genes involved in alcohol metabolism, the natural immune response, the steatotic reaction of the liver, fibrogenesis, or drug metabolism [134,147-150]. However, it may also include genes which do not fall into biological pathways known to be involved in liver disease, identified through systematic genome-wide approaches such as genomewide association studies or, ultimately, genome sequencing. In any case, before such information can be used in a clinical setting, its clinical value has to be demonstrated in adequate clinical studies. To date, only genetic defects that are of prime importance for initiation of disease (for example, in single-gene disorders such as hemochromatosis or Wilson's disease) allow timely intervention and thus prevention of portal hypertension. However, first studies have suggested that common genetic variation in NOD2 (nucleotide-binding oligomerization domaincontaining protein 2) or TLR2 may predispose cirrhotic patients to infectious complications and that patients with certain PNPLA3 variants may be more prone to rapid fibrosis [134,148-150].

It remains to be seen whether decoding of the genome as well as of the microbiome or metabolome with respect to pathways leading to end-stage liver disease will actually enable the definition of targets for timely intervention. This may not work for the treatment of multiple interacting mechanisms. Here, the question arises how this complex information can be integrated in a meaningful way. The major challenge in the realization of the concept of systems biology will require the development of complex computational models. The hope is that by these means disease complications, which in our case is portal hypertension, can be prevented in the future. If this becomes true, there will be a change of paradigms in medicine because judgment of physicians and clinical research will be replaced by computer algorithms.

\section{Other approaches}

It has been shown that inflammation and fibrosis of the liver are influenced by the endocannabinoid system $[151,152]$. CBR2 has protective properties, whereas in different models of liver injury in rodents, upregulation of the CBR1 has been shown to enhance fibrogenesis and steatosis [151,152]. Thus, the respective specific ligands might be suitable for targeting portal hypertension in chronic liver disease as shown in animal studies $[153,154]$, provided that these drugs do not enter the central nervous system where they can cause psychotropic side effects.

Portal hypertension together with liver inflammation induces angiogenesis $[155,156]$, which supports 
splanchnic hyperemia and formation of collaterals [157-159]. Antiangiogenetic therapy (for example, with multikinase inhibitors), already established for treatment of hepatocellular carcinoma [160], reduced portal hypertension in animal models $[157,159,161]$ and in very preliminary pilot studies in humans [162]. However, side effects have to be considered $[155,156,158,161]$. Yet according to animal studies, doses lower than those applied in cancer treatment may effectively blunt portal hypertension in the future.

At the cirrhosis stage, the liver has obviously lost its enormous ability of proper and differentiated renewal. It has been shown in rodent models that mesenchymal or epithelial stem/progenitor cells restore injured parenchyma in fibrotic livers $[163,164]$, and a pilot report on the application of autologous bone marrow-derived stem cells into the hepatic artery in patients with cirrhosis showed subsequent improvement of liver function [165]. Yet hemodynamic studies were not included in these studies, and infarction of liver areas by infused cells might even augment portal hypertension.

\section{Regression of fibrosis/cirrhosis and portal hypertension}

As delineated above, fibrogenesis is a complex process driven by necroinflammation caused by different noxa $[49,166]$. Considerable progress has been made in the characterization of cells, which activate HSCs and stimulate the formation of myofibroblasts $[49,61,167]$. The resulting deposition of collagen is the fixed structural cause of portal hypertension. However, fibrosis (generally divided into a perisinusoidal and septal form) is not synonymous with cirrhosis, the definition of which comprises not only an increase in collagen tissue but also abnormal nodules, neovascularization, and intrahepatic vascular shunts [166], leading to hemodynamic alterations, especially portal hypertension. The possibility of whether full-blown cirrhosis is reversible, which would be the optimal treatment of portal hypertension, has been questioned. However, a few decades ago $[168,169]$, anecdotal reports were published on the disappearance of varices in patients with liver cirrhosis after longer periods of abstinence and on continuous phlebotomy in patients with hemochromatosis or loss of hepatitis B surface antigen. Further reports showed that correction of mechanical cholestasis in patients with chronic pancreatitis [170] or bariatric surgery in patients with NAFLD [171], venesection therapy in genetically proven hemochromatosis [172], or treatment of autoimmune hepatitis [173] led to reduction of different fibrosis scores as assessed by follow-up biopsies. In most of these studies, a change in portal pressure was not systematically determined. One study on a limited number of patients with compensated hepatitis C-related cirrhosis [174], in which interruption of the underlying cause decreased portal hypertension within 12 months after interruption of viremia (even without a change in the histological stage), showed that portal pressure reacts early to reduced inflammation but not necessarily combined with regression of the fibrotic stage.

More recent systematic reviews [175-178] on patients with viral cirrhosis clearly show that suppression or interruption of the underlying cause (viremia) led to histologically proven reversal of liver cirrhosis in around $60 \%$ of patients with a rather broad range $(30 \%$ to $100 \%)$ in the individual studies. Non-invasive techniques, such as elastography, demonstrated even higher response rates [175]. However, it has to be kept in mind that the vast majority of these patients had compensated cirrhosis and that the observed reversal required many years. Furthermore, cirrhosis may even progress in a small number of patients [179] despite a lack of viremia. Interestingly, portal inflammation as well as sinusoidal capillarization persisted even 5 years after interruption of hepatitis C viremia [180].

Better understanding of the process of regression could be a key focus to develop future treatment of portal hypertension. Most of the as-yet-incomplete knowledge derives from studies in rodents. Regeneration of hepatocytes, matrix degradation together with apoptosis, reversal to a quiescent state, or senescence of HSCs is critical $[167,181]$. These events are prevented by certain components of the extracellular matrix (collagen I) with activation of HSCs and induction of an imbalance toward inhibition of extracellular matrix-degrading matrix metalloproteinases $[167,182]$. Macrophages appear to hold a pivotal function in this process since they not only secrete pro-inflammatory cytokines leading to fibrosis but also have a restorative phenotype in the process of degradation of extracellular matrix [61]. In rodents [181], but also in humans [183], remodeling with regression of fibrosis is accompanied by a change from micronodular to macronodular cirrhosis with nodules expanding against fibrotic septa, which are more or less degraded during this process.

\section{Conclusions}

Interruption of mechanisms that initiate and perpetuate portal hypertension in chronic liver disease will remain the ideal approach to counter associated complications. If this is not possible, decrease of intrahepatic resistance by other means is a major goal. Thus, deactivation of pathways that stimulate the main players (HSCs and myofibroblasts) is effective but complex as shown in numerous animal models (Figure 1). Large studies of 
Figure I. Pathophysiology and targets of portal hypertension

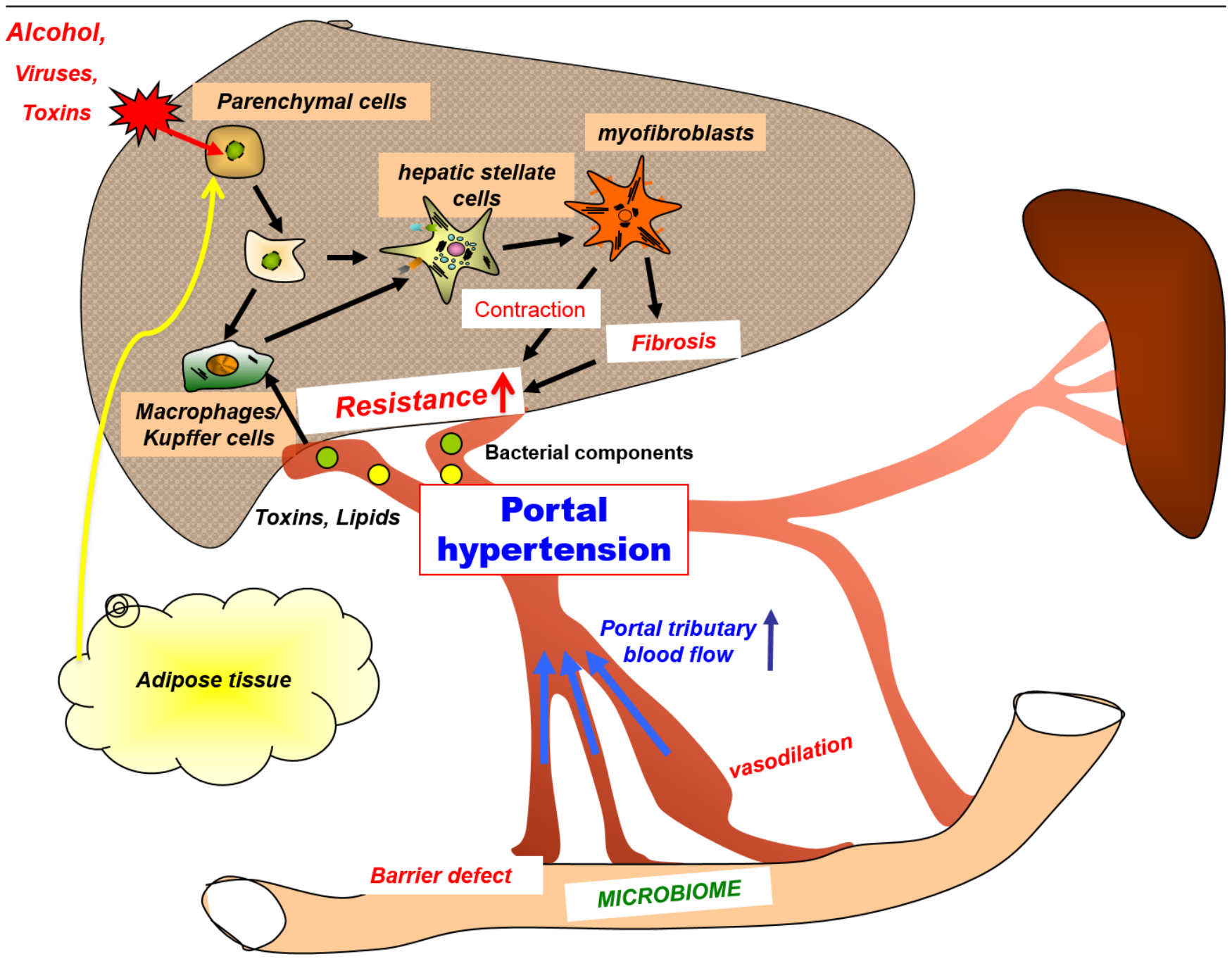

Viruses, alcohol (or other toxins), obesity, lipids, bacterial components, and other factors induce liver damage and inflammation (often via activation of local and recruited macrophages). This process leads to activation of hepatic stellate cells and proliferation of myofibroblasts. Their fibrogenetic and contractile properties are the main causes of increases in intrahepatic resistance and portal venous congestion inducing portal hypertension. This results in splanchnic vasodilation and an increase in portal tributary blood flow via different mechanisms, which aggravate portal hypertension. Initiators of this cascade may reach the liver via the systemic circulation or may be derived from the gut. The best method to counter portal hypertension is the interruption of the initiating events, whether by eradication of hepatotropic viruses, abstinence from alcohol, or weight reduction. If this fails, there are several strategies to modify and influence intrahepatic inflammation or activation (or both) of hepatic stellate cells, including stimuli coming from the gut and the visceral adipose tissue.

humans are still lacking. Shunt procedures are the most rapid and effective measure to decrease portal venous outflow resistance and reduce portal pressure. Yet they can improve survival only to a minor degree if at all. Hence, the increase in portal pressure is a side effect rather than the main cause of the disease. Reduction of the concomitant pro-inflammatory state of patients with liver cirrhosis could provide a further avenue for future investigations. Individualized and personalized treatment and definition of specific risks will become more important. However, it will be difficult to prove all of this by randomized trials.

\section{Abbreviations}

$\mathrm{ACE}$, angiotensin-converting enzyme; AT1R, angiotensin II type I receptor; CBR, cannabinoid receptor; FXR, farnesoid-X receptor; HBV, hepatitis B virus; $\mathrm{HCV}$, hepatitis C virus; HSC, hepatic stellate cell; LPS, lipopolysaccharide; NAFLD, non-alcoholic fatty liver disease; $\mathrm{NASH}$, non-alcoholic steatohepatitis; $\mathrm{NO}$, nitric oxide; 
PNPLA3, patatin-like phospholipase domain-containing protein 3; RAS, renin-angiotensin system; TIPS, transjugular intrahepatic porto-systemic shunt; TLR, Toll-like receptor.

\section{Disclosures}

The authors declare that they have no disclosures.

\section{Acknowledgments}

The authors are supported by Deutsche Forschungsgemeinschaft (SFB TRR57 project 18 -Tilman Sauerbruch and Jonel Trebicka) and by H.W. and J. Hector Stiftung (Jonel Trebicka). We thank Markus Nöthen and Sabine Dentler for critical reading.

\section{References}

I. Vorobioff JD: Hepatic venous pressure in practice: how, when, and why. J Clin Gastroenterol 2007, 4 I (Suppl 3):S336-43.

2. Wong F, Liu P, Tobe S, Morali G, Blendis L: Central blood volume in cirrhosis: measurement with radionuclide angiography. Hepatology 1994, 19:312-21.

3. Blendis L, Wong $\mathrm{F}$ : The hyperdynamic circulation in cirrhosis: an overview. Pharmacol Ther 200I, 89:22I-3I.

4. Lozano R, Naghavi M, Foreman K, Lim S, Shibuya K, Aboyans V, Abraham J, Adair T, Aggarwal R, Ahn SY, Alvarado M, Anderson HR, Anderson LM, Andrews KG, Atkinson C, Baddour LM, BarkerCollo S, Bartels DH, Bell ML, Benjamin EJ, Bennett D, Bhalla K, Bikbov B, Bin Abdulhak A, Birbeck G, Blyth F, Bolliger I, Boufous S, Bucello $C$, Burch $M$, et al.: Global and regional mortality from 235 causes of death for 20 age groups in 1990 and 2010: a systematic analysis for the Global Burden of Disease Study 2010. Lancet 2012, 380:2095-128.

5. European Association For The Study Of The Liver: EASL clinical practice guidelines: Management of chronic hepatitis B virus infection. J Hepatol 2012, 57:167-85.

6. European Association For The Study Of The Liver: EASL Clinical Practice Guidelines: management of hepatitis $C$ virus infection. J Hepatol 2014, 60:392-420.

7. Chung RT, Baumert TF: Curing chronic hepatitis C-the arc of a medical triumph. $N$ Engl J Med 20|4, 370:I576-8.

8. Afdhal N, Zeuzem S, Kwo P, Chojkier M, Gitlin N, Puoti M, RomeroGomez M, Zarski JP, Agarwal K, Buggisch P, Foster GR, Bräu N, Buti M, Jacobson IM, Subramanian GM, Ding $X$, Mo $H$, Yang JC, Pang PS, Symonds WT, McHutchison JG, Muir AJ, Mangia A, Marcellin P; ION-I Investigators: Ledipasvir and sofosbuvir for untreated HCV genotype I infection. N Engl J Med 20I4, 370: $1889-98$

\section{FlOOOPrime}

\section{RECOMMENDED}

9. Afdhal N, Reddy KR, Nelson DR, Lawitz E, Gordon SC, Schiff E, Nahass R, Ghalib R, Gitlin N, Herring R, Lalezari J, Younes ZH, Pockros PJ, Di Bisceglie AM, Arora S, Subramanian GM, Zhu Y, Dvory-Sobol H, Yang JC, Pang PS, Symonds WT, McHutchison JG, Muir AJ, Sulkowski M, Kwo P; ION-2 Investigators: Ledipasvir and sofosbuvir for previously treated HCV genotype I infection. N Engl J Med 2014, 370:1483-93.

\section{FIOOOPrime
RECOMMENDED}

10. Hoofnagle $\mathrm{JH}$, Sherker $\mathrm{AH}$ : Therapy for hepatitis $\mathrm{C}$-the costs of success. $N$ Engl J Med 20I4, 370:1552-3.

\section{FlOOPPrime} RECOMMENDED

II. Marcellin P, Gane E, Buti M, Afdhal N, Sievert W, Jacobson IM, Washington MK, Germanidis G, Flaherty JF, Schall RA, Bornstein JD,
Kitrinos KM, Subramanian GM, McHutchison JG, Heathcote El: Regression of cirrhosis during treatment with tenofovir disoproxil fumarate for chronic hepatitis B: a 5-year openlabel follow-up study. Lancet 2013, 381:468-75.

\section{FlOOOPrime
RECOMMENDED}

12. Arthur MJ: Reversibility of liver fibrosis and cirrhosis following treatment for hepatitis C. Gastroenterology 2002, I 22:I525-8.

13. Kweon YO, Goodman ZD, Dienstag JL, Schiff ER, Brown NA, Burchardt E, Schoonhoven R, Brenner DA, Fried MW: Decreasing fibrogenesis: an immunohistochemical study of paired liver biopsies following lamivudine therapy for chronic hepatitis B. J Hepatol 200I, 35:749-55.

14. Wedemeyer H, Duberg AS, Buti M, Rosenberg WM, Frankova S, Esmat G, Örmeci N, Van Vlierberghe H, Gschwantler M, Akarca U, Aleman S, Balık I, Berg T, Bihl F, Bilodeau M, Blasco AJ, Brandão Mello CE, Bruggmann $P$, Calinas $F$, Calleja JL, Cheinquer $H$, Christensen PB, Clausen M, Coelho HS, Cornberg M, Cramp ME, Dore GJ, Doss W, El-Sayed MH, Ergör G, et al.: Strategies to manage hepatitis $\mathbf{C}$ virus (HCV) disease burden. J Viral Hepat 20I4, 2 I (Suppl I):60-89.

15. European Association For The Study Of The Liver: EASL clinical practical guidelines: management of alcoholic liver disease. J Hepatol 2012, 57:399-420.

16. Zatonski WA, Sulkowska U, Manczuk M, Rehm J, Boffetta P, Lowenfels $A B$, La Vecchia C: Liver cirrhosis mortality in Europe, with special attention to Central and Eastern Europe. Eur Addict Res 2010, 16:193-201.

17. Holm AL, Veerman L, Cobiac L, Ekholm O, Diderichsen F: Costeffectiveness of preventive interventions to reduce alcohol consumption in Denmark. PLoS One 2014, 9:e8804I.

18. Holm AL, Veerman L, Cobiac L, Ekholm O, Diderichsen F: Costeffectiveness of changes in alcohol taxation in Denmark: a modelling study. Cost Eff Resour Alloc 2014, I 2:I.

19. Schnabl B, Brenner DA: Interactions between the intestinal microbiome and liver diseases. Gastroenterology 2014, 146:1513-24.

20. Liedtke C, Luedde T, Sauerbruch T, Scholten D, Scholten D, Streetz K, Tacke F, Tolba R, Trautwein C, Trebicka J, Weiskirchen R: Experimental liver fibrosis research: update on animal models, legal issues and translational aspects. Fibrogenesis Tissue Repair 2013, 6:19.

21. Mathews S, Xu M, Wang H, Bertola A, Gao B: Animals Models of Gastrointestinal and Liver Diseases. Animal models of alcohol-induced liver disease: pathophysiology, translational relevance, and challenges. Am J Physiol Gastrointest Liver Physiol 2014, 306:G819-23.

22. Nadalin S, Malago M, Valentin-Gamazo C, Testa G, Baba HA, Liu C, Frühauf NR, Schaffer R, Gerken G, Frilling A, Broelsch CE: Preoperative donor liver biopsy for adult living donor liver transplantation: risks and benefits. Liver Transpl 2005, I I:980-6.

23. Minervini MI, Ruppert K, Fontes P, Volpes R, Volpes R, Vizzini G, de Vera ME, Gruttadauria S, Miraglia R, Pipitone L, Marsh JW, Marcos A, Gridelli $B$, Demetris AJ: Liver biopsy findings from healthy potential living liver donors: reasons for disqualification, silent diseases and correlation with liver injury tests. J Hepatol 2009, 50:501-10.

24. Anstee QM, Targher G, Day CP: Progression of NAFLD to diabetes mellitus, cardiovascular disease or cirrhosis. Nat Rev Gastroenterol Hepatol 2013, 10:330-44.

25. Adams LA, Lymp JF, St Sauver J, Sanderson SO, Lindor KD, Feldstein A, Angulo P: The natural history of nonalcoholic fatty liver disease: a populationbased cohort study. Gastroenterology 2005, I 29: I I3-2I.

26. Mendes FD, Suzuki A, Sanderson SO, Lindor KD, Angulo P: Prevalence and indicators of portal hypertension in patients with nonalcoholic fatty liver disease. Clin Gastroenterol Hepatol 2012, 10:1028-33. el022.

27. Ekstedt M, Franzen LE, Mathiesen UL, Thorelius L, Holmqvist M, Bodemar G, Kechagias S: Long-term follow-up of patients with 
NAFLD and elevated liver enzymes. Hepatology 2006, 44:865-73.

28. Argo CK, Caldwell SH: Epidemiology and natural history of nonalcoholic steatohepatitis. Clin Liver Dis 2009, I3:5 I I-3I.

29. Argo CK, Northup PG, Al-Osaimi AM, Caldwell SH: Systematic review of risk factors for fibrosis progression in non-alcoholic steatohepatitis. J Hepatol 2009, 5 1:37I-9.

30. Ratziu V, Bellentani S, Cortez-Pinto H, Day C, Marchesini G: A position statement on NAFLD/NASH based on the EASL 2009 special conference. J Hepatol 2010, 53:372-84.

3I. Angulo P: GI epidemiology: nonalcoholic fatty liver disease. Aliment Pharmacol Ther 2007, 25:883-9.

32. Dongiovanni P, Donati B, Fares R, Lombardi R, Mancina RM, Romeo S, Valenti L: PNPLA3 II 48M polymorphism and progressive liver disease. World J Gastroenterol 2013, 19:6969-78.

33. Anstee $\mathrm{QM}$, McPherson S, Day CP: How big a problem is nonalcoholic fatty liver disease? BMJ 20I I, 343:d3897.

34. Lassailly G, Caiazzo R, Hollebecque A, Buob D, Leteurtre E, Arnalsteen L, Louvet A, Pigeyre M, Raverdy V, Verkindt H, Six MF, Eberle C, Patrice A, Dharancy S, Romon M, Pattou F, Mathurin P: Validation of noninvasive biomarkers (FibroTest, SteatoTest, and NashTest) for prediction of liver injury in patients with morbid obesity. Eur J Gastroenterol Hepatol 20 I I, 23:499-506.

35. Promrat $K$, Kleiner DE, Niemeier HM, Jackvony E, Kearns $M$, Wands JR, Fava JL, Wing RR: Randomized controlled trial testing the effects of weight loss on nonalcoholic steatohepatitis. Hepatology 2010, 5 I:121-9.

36. Chavez-Tapia NC, Tellez-Avila Fl, Barrientos-Gutierrez T, MendezSanchez N, Lizardi-Cervera J, Uribe M: Bariatric surgery for nonalcoholic steatohepatitis in obese patients. Cochrane Database Syst Rev 2010, I:CD007340.

\section{FlOOOPrime}

\section{RECOMMENDED}

37. Mosko JD, Nguyen GC: Increased perioperative mortality following bariatric surgery among patients with cirrhosis. Clin Gastroenterol Hepatol 201 I, 9:897-90I.

38. Ostlund MP, Backman O, Marsk R, Stockeld D, Lagergren J, Rasmussen F, Naslund E: Increased admission for alcohol dependence after gastric bypass surgery compared with restrictive bariatric surgery. JAMA Surg 20I3, I48:374-7.

39. Felipo V, Urios A, Garcia-Torres ML, El Mlili N, del Olmo JA, del Olmo JA, Civera M, Ortega J, Ferrandez A, Martínez-Valls J, Cassinello N, Montoliu C: Alterations in adipocytokines and cGMP homeostasis in morbid obesity patients reverse after bariatric surgery. Obesity (Silver Spring) 2013, 21 1:229-37.

40. Lassailly G, Caiazzo R, Pattou F, Mathurin P: Bariatric surgery for curing NASH in the morbidly obese? J Hepatol 20I3, 58: I 249-5I.

4I. Trebicka J, Hennenberg M, Laleman W, Shelest N, Shelest N, Biecker E, Schepke M, Nevens F, Sauerbruch T, Heller J: Atorvastatin lowers portal pressure in cirrhotic rats by inhibition of RhoA/Rho-kinase and activation of endothelial nitric oxide synthase. Hepatology 2007, 46:242-53.

42. Trebicka J, Hennenberg M, Odenthal M, Shir K, Klein S, Granzow M, Vogt A, Dienes HP, Lammert F, Reichen J, Heller J, Sauerbruch T: Atorvastatin attenuates hepatic fibrosis in rats after bile duct ligation via decreased turnover of hepatic stellate cells. J Hepatol 2010, 53:702-12.

43. Klein S, Klosel J, Schierwagen R, Körner C, Granzow M, Huss S, Mazar IG, Weber S, van den Ven PF, Pieper-Fürst U, Fürst DO, Nattermann J, Lammert F, Sauerbruch T, Trebicka J: Atorvastatin inhibits proliferation and apoptosis, but induces senescence in hepatic myofibroblasts and thereby attenuates hepatic fibrosis in rats. Lab Invest 2012, 92:1440-50.

44. Shirai Y, Yoshiji H, Noguchi R, Kaji K, Aihara Y, Douhara A, Moriya K, Namisaki T, Kawaratani H, Fukui H: Cross talk between toll-like receptor-4 signaling and angiotensin-II in liver fibrosis development in the rat model of non-alcoholic steatohepatitis. J Gastroenterol Hepatol 2013, 28:723-30.
45. Toblli JE, Munoz MC, Cao G, Mella J, Pereyra L, Mastai R: ACE inhibition and ATI receptor blockade prevent fatty liver and fibrosis in obese Zucker rats. Obesity (Silver Spring) 2008, 16:770-6.

46. Kudo H, Yata Y, Takahara T, Kawai K, Nakayama Y, Kanayama M, Oya T, Morita S, Sasahara M, Mann DA, Sugiyama T: Telmisartan attenuates progression of steatohepatitis in mice: role of hepatic macrophage infiltration and effects on adipose tissue. Liver Int 2009, 29:988-96.

47. Kato J, Koda M, Kishina M, Tokunaga S, Matono T, Sugihara T, Sugihara T, Ueki M, Murawaki $Y$ : Therapeutic effects of angiotensin II type I receptor blocker, irbesartan, on nonalcoholic steatohepatitis using FLS-ob/ob male mice. Int J Mol Med 2012, 30:107-13.

48. Friedman SL: Mechanisms of hepatic fibrogenesis. Gastroenterology 2008, I34:1655-69.

49. Schuppan D, Kim YO: Evolving therapies for liver fibrosis. J Clin Invest 2013, I 23:|887-90|

50. Pellicoro A, Ramachandran P, Iredale JP, Fallowfield JA: Liver fibrosis and repair: immune regulation of wound healing in a solid organ. Nat Rev Immunol 2014, I4: I8I-94.

5I. Patsenker E, Popov Y, Stickel F, Jonczyk A, Goodman SL, Schuppan D: Inhibition of integrin alphavbeta6 on cholangiocytes blocks transforming growth factor-beta activation and retards biliary fibrosis progression. Gastroenterology 2008, I35:660-70.

\section{FlOOOPrime}

\section{RECOMMENDED}

52. Patsenker E, Popov Y, Stickel F, Schneider V, Ledermann M, Sägesser H, Niedobitek G, Goodman SL, Schuppan D: Pharmacological inhibition of integrin alphavbeta3 aggravates experimental liver fibrosis and suppresses hepatic angiogenesis. Hepatology 2009, 50:1501-II.

53. Henderson NC, Arnold TD, Katamura $Y$, Giacomini MM Rodriguez JD, McCarty JH, Pellicoro A, Raschperger E, Betsholtz C, Ruminski PG, Griggs DW, Prinsen MJ, Maher JJ, Iredale JP, LacyHulbert A, Adams RH, Sheppard D: Targeting of alphav integrin identifies a core molecular pathway that regulates fibrosis in several organs. Nat Med 2013, 19:1617-24.

\section{FlOOOPrime}

54. Pinzani M, Milani S, De Franco R, Grappone C, Caligiuri A, Gentilini A, Tosti-Guerra C, Maggi M, Failli P, Ruocco C, Gentilini P: Endothelin $I$ is overexpressed in human cirrhotic liver and exerts multiple effects on activated hepatic stellate cells. Gastroenterology 1996, I I 0:534-48.

55. Svegliati-Baroni G, Ridolfi F, Caradonna Z, Alvaro D, Marzioni M, Saccomanno S, Candelaresi C, Trozzi L, Macarri G, Benedetti A, Folli F: Regulation of ERK/JNK/p70S6K in two rat models of liver injury and fibrosis. J Hepatol 2003, 39:528-37.

56. Sancho-Bru P, Bataller R, Colmenero J, Gasull X, Moreno M, Arroyo V, Brenner DA, Ginès P: Norepinephrine induces calcium spikes and proinflammatory actions in human hepatic stellate cells. Am J Physiol Gastrointest Liver Physiol 2006, 291:G877-84.

57. Verbeke L, Farre R, Trebicka J, Komuta M, Roskams T, Klein S, Elst IV, Windmolders P, Vanuytsel T, Nevens F, Laleman W: Obeticholic acid, a farnesoid $X$ receptor agonist, improves portal hypertension by two distinct pathways in cirrhotic rats. Hepatology 2014, 59:2286-98.

58. Granzow M, Schierwagen R, Klein S, Kowallick B, Huss S, Linhart M, Mazar IG, Görtzen J, Vogt A, Schildberg FA, Gonzalez-Carmona MA, Wojtalla A, Krämer B, Nattermann J, Siegmund SV, Werner N, Fürst DO, Laleman W, Knolle P, Shah VH, Sauerbruch T, Trebicka J: Angiotensin-II type I receptor-mediated Janus kinase 2 activation induces liver fibrosis. Hepatology 2014, 60:334-48.

59. Li T, Eheim AL, Klein S, Uschner FE, Smith AC, Smith AC, BrandonWarner E, Ghosh S, Bonkovsky HL, Trebicka J, Schrum LW: Novel role of nuclear receptor Rev-erbalpha in hepatic stellate cell 
activation: potential therapeutic target for liver injury. Hepatology 2014, 59:2383-96.

\section{FIOOOPrime}

60. Ehling J, Bartneck M, Wei X, Gremse F, Fech V, Möckel D, Baeck C, Hittatiya K, Eulberg D, Luedde T, Kiessling F, Trautwein C, Lammers T, Tacke F: CCL2-dependent infiltrating macrophages promote angiogenesis in progressive liver fibrosis. Gut 2014, [Epub ahead of print]

61. Tacke F, Zimmermann HW: Macrophage heterogeneity in liver injury and fibrosis. J Hepatol 20I4, 60:1090-6.

62. Heller J, Shiozawa T, Trebicka J, Hennenberg M, Schepke M, Neef M, Sauerbruch T: Acute haemodynamic effects of losartan in anaesthetized cirrhotic rats. Eur J Clin Invest 2003, 33:1006-1012.

63. Heller J, Trebicka J, Shiozawa T, Schepke M, Neef M, Hennenberg M, Sauerbruch T: Vascular, hemodynamic and renal effects of lowdose losartan in rats with secondary biliary cirrhosis. Liver Int 2005, 25:657-66.

64. Zhou Q, Hennenberg M, Trebicka J, Jochem K, Jochem K, Leifeld L, Biecker E, Sauerbruch T, Heller J: Intrahepatic upregulation of RhoA and Rho-kinase signalling contributes to increased hepatic vascular resistance in rats with secondary biliary cirrhosis. Gut 2006, 55:1296-305.

65. Hennenberg M, Biecker E, Trebicka J, Jochem K, Zhou Q, Schmidt M, Jakobs KH, Sauerbruch T, Heller J: Defective RhoA/Rho-kinase signaling contributes to vascular hypocontractility and vasodilation in cirrhotic rats. Gastroenterology 2006, 130:838-54.

66. Moreno M, Gonzalo T, Kok RJ, Sancho-Bru P, van Beuge M, Swart J, Prakash J, Temming K, Fondevila C, Beljaars L, Lacombe M, van der Hoeven P, Arroyo V, Poelstra K, Brenner DA, Ginès P, Bataller R: Reduction of advanced liver fibrosis by short-term targeted delivery of an angiotensin receptor blocker to hepatic stellate cells in rats. Hepatology 2010, 5 1:942-52.

\section{FlOOOPrime} RECOMMENDED

67. van Beuge MM, Prakash J, Lacombe M, Gosens R, Post E, RekerSmit C, Beljaars L, Poelstra K: Reduction of fibrogenesis by selective delivery of a Rho kinase inhibitor to hepatic stellate cells in mice. J Pharmacol Exp Ther 201I, 337:628-35.

68. van Beuge MM, Prakash J, Lacombe M, Post E, Reker-Smit C, Beljaars L, Poelstra K: Increased Liver Uptake and Reduced Hepatic Stellate Cell Activation with a Cell-Specific Conjugate of the Rho-kinase Inhibitor Y27632. Pharm Res 20II, 28:2045-54.

\section{FlOOOPrime}

69. Klein S, Van Beuge MM, Granzow M, Beljaars L, Schierwagen R, Kilic S, Heidari I, Huss S, Sauerbruch T, Poelstra K, Trebicka J: HSC-specific inhibition of Rho-kinase reduces portal pressure in cirrhotic rats without major systemic effects. J Hepatol 2012, 57:1220-7.

70. Bansal R, Prakash J, Post E, Beljaars L, Schuppan D, Poelstra K: Novel engineered targeted interferon-gamma blocks hepatic fibrogenesis in mice. Hepatology 201 I, 54:586-96.

\section{FlOOOPrime \\ RECOMMENDED}

71. Melgert BN, Olinga P, Van Der Laan JM, Weert B, Cho J, Schuppan D, Groothuis GM, Meijer DK, Poelstra K: Targeting dexamethasone to Kupffer cells: effects on liver inflammation and fibrosis in rats. Hepatology 200I, 34:719-28.

72. Bartneck M, Peters FM, Warzecha KT, Bienert M, van Bloois L, Trautwein C, Lammers T, Tacke F: Liposomal encapsulation of dexamethasone modulates cytotoxicity, inflammatory cytokine response, and migratory properties of primary human macrophages. Nanomedicine 2014, 10:1209-20.
73. Steib CJ, Hennenberg M, Beitinger F, Hartmann AC, Bystron M, De Toni EN, Gerbes AL: Amiloride reduces portal hypertension in rat liver cirrhosis. Gut 2010, 59:827-36.

\section{FlOOPrime}

\section{RECOMMENDED}

74. Steib CJ, Bilzer M, op den Winkel M, Pfeiler S, Hartmann AC, Hennenberg M, Göke B, Gerbes AL: Treatment with the leukotriene inhibitor montelukast for 10 days attenuates portal hypertension in rat liver cirrhosis. Hepatology 20 10, 5 I:2086-96.

\section{FIOOOPrime
RECOMMENDED}

75. Lin HC, Yang YY, Tsai TH, Huang CM, Huang YT, Lee FY, Liu TT, Lee SD: The relationship between endotoxemia and hepatic endocannabinoids in cirrhotic rats with portal hypertension. J Hepatol 201I, 54: I I45-53.

76. Steib CJ: Kupffer cell activation and portal hypertension. Gut 201I, 60:1307-08.

77. Holland-Fischer P, Gronbaek H, Sandahl TD, Moestrup SK, Riggio O, Ridola L, Aagaard NK, Møller HJ, Vilstrup H: Kupffer cells are activated in cirrhotic portal hypertension and not normalised by TIPS. Gut 2011, 60:1389-93.

\section{FlOOOPrime} RECOMMENDED

78. Trebicka J, Krag A, Gansweid S, Appenrodt B, Schiedermaier P, Sauerbruch T, Spengler U: Endotoxin and tumor necrosis factorreceptor levels in portal and hepatic vein of patients with alcoholic liver cirrhosis receiving elective transjugular intrahepatic portosystemic shunt. Eur J Gastroenterol Hepatol 201I, 23:12| $18-25$.

79. Trebicka J, Krag A, Gansweid S, Schiedermaier P, Strunk HM, Fimmers R, Strassburg CP, Bendtsen F, Møller S, Sauerbruch T, Spengler U: Soluble TNF-alpha-receptors I are prognostic markers in TIPS-treated patients with cirrhosis and portal hypertension. PLoS One 2013, 8:e8334I.

80. Wiest R, Groszmann RJ: Nitric oxide and portal hypertension: its role in the regulation of intrahepatic and splanchnic vascular resistance. Semin Liver Dis 1999, 19:41 I-26.

8I. Fiorucci S, Antonelli E, Morelli O, Mencarelli A, Casini A, Mello T, Palazzetti B, Tallet D, del Soldato P, Morelli A: NCX-1000, a NOreleasing derivative of ursodeoxycholic acid, selectively delivers NO to the liver and protects against development of portal hypertension. Proc Natl Acad Sci USA 200I, 98:8897-902.

82. Fiorucci S, Antonelli E, Tocchetti P, Morelli A: Treatment of portal hypertension with NCX-1000, a liver-specific NO donor. A review of its current status. Cardiovasc Drug Rev 2004, 22: I35-46.

83. Biecker E, Trebicka J, Kang A, Hennenberg M, Sauerbruch T, Heller J: Treatment of bile duct-ligated rats with the nitric oxide synthase transcription enhancer AVE 9488 ameliorates portal hypertension. Liver Int 2008, 28:33I-8.

84. Zafra C, Abraldes JG, Turnes J, Berzigotti A, Fernandez M, GarcaPagán JC, Rodés J, Bosch J: Simvastatin enhances hepatic nitric oxide production and decreases the hepatic vascular tone in patients with cirrhosis. Gastroenterology 2004, I 26:749-55.

\section{FlOOOPrime
RECOMMENDED}

85. Abraldes JG, Rodriguez-Vilarrupla A, Graupera M, Zafra C, GarciaCaldero H, Garcia-Pagan JC, Bosch J: Simvastatin treatment improves liver sinusoidal endothelial dysfunction in $\mathrm{CCl} 4$ cirrhotic rats. J Hepatol 2007, 46: 1040-6.

86. Abraldes JG, Albillos A, Banares R, Turnes J, Gonzalez R, GarciaPagan JC, Bosch J: Simvastatin lowers portal pressure in patients with cirrhosis and portal hypertension: a randomized controlled trial. Gastroenterology 2009, 136:165I-8.

\section{FlOOOPrime}

RECOMMENDED

87. Woitas RP, Heller J, Stoffel-Wagner B, Spengler U, Sauerbruch T: Renal functional reserve and nitric oxide in patients with compensated liver cirrhosis. Hepatology 1997, 26:858-64. 
88. Woitas RP, Flommersfeld S, Stoffel-Wagner B, Schiedermaier P, Brensing KA, Spengler U, Sauerbruch T: Renal functional reserve is well maintained in patients with advanced liver cirrhosis and ascites. Scand J Gastroenterol 2002, 37:|321-7.

89. Kobori H, Nangaku M, Navar LG, Nishiyama A: The intrarenal reninangiotensin system: from physiology to the pathobiology of hypertension and kidney disease. Pharmacol Rev 2007, 59:25 I-87.

90. Bataller R, Sancho-Bru P, Gines P, Brenner DA: Liver fibrogenesis: a new role for the renin-angiotensin system. Antioxid Redox Signal 2005, 7:1346-55.

91. Schrier RW, Arroyo V, Bernardi M, Epstein M, Henriksen JH, Rodes J: Peripheral arterial vasodilation hypothesis: a proposal for the initiation of renal sodium and water retention in cirrhosis. Hepatology 1988, 8:1 I5I-7.

92. Oakley F, Teoh V, Ching ASG, Bataller R, Colmenero J, Jonsson JR, Eliopoulos AG, Watson MR, Manas D, Mann DA: Angiotensin II activates I kappaB kinase phosphorylation of RelA at Ser 536 to promote myofibroblast survival and liver fibrosis. Gastroenterology 2009, I36:2334-44. e2331.

93. Bataller R, Gines P, Nicolas JM, Gorbig MN, Garcia-Ramallo E, Gasull X, Bosch J, Arroyo V, Rodés J: Angiotensin II induces contraction and proliferation of human hepatic stellate cells. Gastroenterology 2000, I | 8: | |49-56.

94. Bataller R, Gabele E, Parsons CJ, Morris T, Yang L, Schoonhoven R, Brenner DA, Rippe RA: Systemic infusion of angiotensin II exacerbates liver fibrosis in bile duct-ligated rats. Hepatology 2005, 4 I: 1046-55.

95. Yang L, Bataller R, Dulyx J, Coffman TM, Gines P, Rippe RA, Brenner DA: Attenuated hepatic inflammation and fibrosis in angiotensin type Ia receptor deficient mice. J Hepatol 2005, 43:317-23.

96. Wei Y, Clark SE, Morris EM, Thyfault JP, Uptergrove GM, WhaleyConnell AT, Ferrario CM, Sowers JR, Ibdah JA: Angiotensin II-induced non-alcoholic fatty liver disease is mediated by oxidative stress in transgenic TG(mRen2)27(Ren2) rats. J Hepatol 2008, 49:4I7-28.

97. Grace JA, Herath CB, Mak KY, Burrell LM, Angus PW: Update on new aspects of the renin-angiotensin system in liver disease: clinical implications and new therapeutic options. Clin Sci (Lond) 2012, I 23:225-39.

98. Tandon P, Abraldes JG, Berzigotti A, Garcia-Pagan JC, Bosch J: Reninangiotensin-aldosterone inhibitors in the reduction of portal pressure: a systematic review and meta-analysis. J Hepatol 2010, 53:273-82

99. Schneider AW, Kalk JF, Klein CP: Effect of losartan, an angiotensin II receptor antagonist, on portal pressure in cirrhosis. Hepatology 1999, 29:334-9.

100. Schepke M, Werner E, Biecker E, Schiedermaier P, Heller J, Neef M, Stoffel-Wagner B, Hofer U, Caselmann WH, Sauerbruch T: Hemodynamic effects of the angiotensin II receptor antagonist irbesartan in patients with cirrhosis and portal hypertension. Gastroenterology 2001, I 2 1:389-95.

101. Girgrah N, Liu P, Collier J, Blendis L, Wong F: Haemodynamic, renal sodium handling, and neurohormonal effects of acute administration of low dose losartan, an angiotensin II receptor antagonist, in preascitic cirrhosis. Gut 2000, 46:1 14-20.

102. Wong F, Liu P, Blendis L: The mechanism of improved sodium homeostasis of low-dose losartan in preascitic cirrhosis. Hepatology 2002, 35:1449-58.

103. Schepke M, Wiest R, Flacke S, Heller J, Stoffel-Wagner B, Herold T, Ghauri M, Sauerbruch T: Irbesartan plus low-dose propranolol versus low-dose propranolol alone in cirrhosis: a placebocontrolled, double-blind study. Am J Gastroenterol 2008, 103:I I52-8.

104. Grace JA, Klein S, Herath CB, Granzow M, Schierwagen R, Masing N, Walther T, Sauerbruch T, Burrell LM, Angus PW, Trebicka J: Activation of the MAS receptor by angiotensin-(1-7) in the renin-angiotensin system mediates mesenteric vasodilatation in cirrhosis. Gastroenterology 2013, I45:874-84. e875.

105. Antunes LC, Davies JE, Finlay BB: Chemical signaling in the gastrointestinal tract. FI000 Biol Rep 20II, 3:4.
106. Henao-Mejia J, Elinav E, Strowig T, Flavell RA: Inflammasomes: far beyond inflammation. Nat Immunol 20I2, I3:32I-4.

107. Strowig T, Henao-Mejia J, Elinav E, Flavell R: Inflammasomes in health and disease. Nature 2012, 48I:278-86.

108. Szabo G, Csak T: Inflammasomes in liver diseases. J Hepatol 20I2, 57:642-54.

109. Henao-Mejia J, Elinav E, Jin C, Hao L, Mehal WZ, Strowig T, Thaiss CA, Kau AL, Eisenbarth SC, Jurczak MJ, Camporez JP, Shulman GI, Gordon JI, Hoffman HM, Flavell RA: Inflammasomemediated dysbiosis regulates progression of NAFLD and obesity. Nature 2012, 482:179-85.

\section{FlOOOPrime
RECOMMENDED}

I I0. Lepage $P$, Leclerc $M C$, Joossens $M$, Mondot $S$, Blottière HM, Raes J, Ehrlich D, Doré J: A metagenomic insight into our gut's microbiome. Gut 2013, 62:146-58.

III. Vlachogiannakos J, Saveriadis AS, Viazis N, Theodoropoulos I, Foudoulis K, Manolakopoulos S, Raptis S, Karamanolis DG: Intestinal decontamination improves liver haemodynamics in patients with alcohol-related decompensated cirrhosis. Aliment Pharmacol Ther 2009, 29:992-99.

II2. Kalambokis GN, Mouzaki A, Rodi M, Pappas K, Fotopoulos A, Xourgia X, Tsianos EV: Rifaximin improves systemic hemodynamics and renal function in patients with alcohol-related cirrhosis and ascites. Clin Gastroenterol Hepatol 2012, 10:815-8.

\section{FlOOOPrime
RECOMMENDED}

II3. Vlachogiannakos J, Viazis $\mathrm{N}$, Vasianopoulou P, Vafiadis I, Karamanolis DG, Ladas SD: Long-term administration of rifaximin improves the prognosis of patients with decompensated alcoholic cirrhosis. J Gastroenterol Hepatol 20I3, 28:450-5.

II4. Papatheodoridis GV, Goulis J, Leandro G, Patch D, Burroughs AK: Transjugular intrahepatic portosystemic shunt compared with endoscopic treatment for prevention of variceal rebleeding: A meta-analysis. Hepatology 1999, 30:612-22.

II5. Burroughs AK, Vangeli M: Transjugular intrahepatic portosystemic shunt versus endoscopic therapy: randomized trials for secondary prophylaxis of variceal bleeding: an updated metaanalysis. Scand J Gastroenterol 2002, 37:249-52.

I 16. Inagaki T, Moschetta A, Lee YK, Peng L, Zhao G, Downes M, Yu RT, Shelton JM, Richardson JA, Repa J, Mangelsdorf DJ, Kliewer SA: Regulation of antibacterial defense in the small intestine by the nuclear bile acid receptor. Proc Nat Acad Sci USA 2006, 103:3920-5.

\section{FlOOOPrime}

\section{RECOMMENDED}

II7. Stojancevic M, Stankov K, Mikov M: The impact of farnesoid $\mathbf{X}$ receptor activation on intestinal permeability in inflammatory bowel disease. Can J Gastroenterol 20I2, 26:631-7.

I18. Verbeke L, Farre R, Covens K, Verbinnen BV, T., Elst IV, Windmolders PV, J., Komuta M, Roskams T, Trebicka J, Nevens F, Laleman W: Obeticholic acid, a Farnesoid-X Receptor-agonist, reduces bacterial translocation and restores intestinal permeability in a rat model of cholestatic liver disease. $\int$ Hepatol 20I4, 60:SI-22.

I19. D'Amico G, Pagliaro L, Bosch J: The treatment of portal hypertension: a meta-analytic review. Hepatology 1995, 22:332-54.

120. Conn HO, Lindenmuth WW: Prophylactic Portacaval Anastomosis in Cirrhotic Patients with Esophageal Varices: A Progress Report of a Continuing Study. N Engl J Med 1965, 272: $1255-63$.

121. Ring EJ, Lake JR, Roberts JP, Gordon RL, LaBerge JM, Read AE, Sterneck MR, Ascher NL: Using transjugular intrahepatic portosystemic shunts to control variceal bleeding before liver transplantation. Ann Intern Med 1992, I I 6:304-9.

122. Rossle M: TIPS: 25 years later. J Hepatol 2013, 59:1081-93.

123. Brensing KA, Textor J, Perz J, Schiedermaier P, Schiedermaier P, Raab P, Strunk H, Klehr HU, Kramer HJ, Spengler U, Schild H, Sauerbruch T: Long term outcome after transjugular intrahepatic 
portosystemic stent-shunt in non-transplant cirrhotics with hepatorenal syndrome: a phase II study. Gut 2000, 47:288-95.

124. Monescillo A, Martinez-Lagares F, Ruiz-del-Arbol L, Sierra A, Guevara C, Jiménez E, Marrero JM, Buceta $E$, Sánchez J, Castellot $A$, Peñate $M$, Cruz A, Peña E: Influence of portal hypertension and its early decompression by TIPS placement on the outcome of variceal bleeding. Hepatology 2004, 40:793-80I.

125. Garcia-Pagan JC, Caca K, Bureau C, Laleman W, Appenrodt B, Luca A, Abraldes JG, Nevens F, Vinel JP, Mössner J, Bosch J: Early use of TIPS in patients with cirrhosis and variceal bleeding. $N$ Engl J Med 2010, 362:2370-9.

\section{FlOOOPrime
RECOMMENDED}

126. Garcia-Pagan JC, Di Pascoli M, Caca K, Laleman W, Bureau C, Appenrodt B, Luca A, Zipprich A, Abraldes JG, Nevens F, Vinel JP, Sauerbruch T, Bosch J: Use of early-TIPS for high-risk variceal bleeding: results of a post-RCT surveillance study. J Hepatol 2013, 58:45-50.

\section{FIOOOPrime}

I27. Orloff MJ: Fifty-three years' experience with randomized clinical trials of emergency portacaval shunt for bleeding esophageal varices in Cirrhosis: 1958-20 I I. JAMA Surg 20I4, I49:I55-69.

128. Goulis J, Patch D, Burroughs AK: Bacterial infection in the pathogenesis of variceal bleeding. Lancet 1999, 353:|39-42.

129. Goulis J, Armonis A, Patch D, Sabin C, Greenslade L, Burroughs AK: Bacterial infection is independently associated with failure to control bleeding in cirrhotic patients with gastrointestinal hemorrhage. Hepatology 1998, 27:1207-12.

130. Moreau R, Jalan R, Gines P, Pavesi M, Angeli P, Cordoba J, Durand F, Gustot T, Saliba F, Domenicali M, Gerbes A, Wendon J, Alessandria C, Laleman W, Zeuzem S, Trebicka J, Bernardi M, Arroyo V; CANONIC Study Investigators of the EASL-CLIF Consortium: Acute-onchronic liver failure is a distinct syndrome that develops in patients with acute decompensation of cirrhosis. Gastroenterology 2013, I44:|426-37, |437e|42|-|429.

\section{FlOOOPrime
RECOMMENDED}

I3I. Ioannou GN, Kowdley KV: Review: antibiotic prophylaxis reduces mortality and bacterial infection in cirrhosis and gastrointestinal bleeding. ACP J Club 2002, I37:94.

132. Bernard B, Grange JD, Khac EN, Amiot X, Opolon P, Poynard T: Antibiotic prophylaxis for the prevention of bacterial infections in cirrhotic patients with gastrointestinal bleeding: a meta-analysis. Hepatology 1999, 29:|655-6I.

I33. Bruns T, Peter J, Reuken PA, Grabe DH, Schuldes SR, Brenmoehl J, Schölmerich J, Wiest R, Stallmach A: NOD2 gene variants are a risk factor for culture-positive spontaneous bacterial peritonitis and monomicrobial bacterascites in cirrhosis. Liver Int 20I2, 32:223-30

134. Appenrodt B, Grunhage F, Gentemann MG, Thyssen L, Sauerbruch T, Lammert F: Nucleotide-binding oligomerization domain containing 2 (NOD2) variants are genetic risk factors for death and spontaneous bacterial peritonitis in liver cirrhosis. Hepatology 2010, 5 I:1327-33.

135. Jalan R, Fernandez J, Wiest R, Schnabl B, Moreau R, Angeli P, Stadlbauer V, Gustot T, Bernardi M, Canton R, Albillos A, Lammert F, Wilmer A, Mookerjee R, Vila J, Garcia-Martinez R, Wendon J, Such J, Cordoba J, Sanyal A, Garcia-Tsao G, Arroyo V, Burroughs A, Ginès P: Bacterial infections in cirrhosis: A position statement based on the EASL Special Conference 2013. J Hepatol 2014, 60:1310-24.

136. Groszmann RJ: Beta-adrenergic blockers and nitrovasodilators for the treatment of portal hypertension: the good, the bad, the ugly. Gastroenterology 1997, I I 3:1794-7.

137. Hennenberg M, Trebicka J, Sauerbruch T, Heller J: Mechanisms of extrahepatic vasodilation in portal hypertension. Gut 2008, 57:1300-14.
I38. Trebicka J, Hennenberg M, Schulze Pröbsting A, Laleman W, Klein S, Granzow M, Nevens F, Zaagsma J, Heller J, Sauerbruch T: Role of beta3-adrenoceptors for intrahepatic resistance and portal hypertension in liver cirrhosis. Hepatology 2009, 50:1924-35.

139. Lebrec D, Nouel O, Corbic M, Benhamou JP: Propranolol-a medical treatment for portal hypertension? Lancet 1980, 2:180-2.

140. Lebrec D, Hillon P, Munoz C, Goldfarb G, Nouel O, Benhamou JP: The effect of propranolol on portal hypertension in patients with cirrhosis: a hemodynamic study. Hepatology 1982, 2:523-7.

14I. Poynard T, Cales P, Pasta L, Ideo G, Pascal JP, Pagliaro L, Lebrec D: Beta-adrenergic-antagonist drugs in the prevention of gastrointestinal bleeding in patients with cirrhosis and esophageal varices. An analysis of data and prognostic factors in $\mathbf{5 8 9}$ patients from four randomized clinical trials. Franco-Italian Multicenter Study Group. N Engl J Med I99I, 324:1532-8.

142. Tripathi D, Ferguson JW, Kochar N, Leithead JA, Therapondos G, McAvoy NC, Stanley AJ, Forrest EH, Hislop WS, Mills PR, Hayes PC: Randomized controlled trial of carvedilol versus variceal band ligation for the prevention of the first variceal bleed. Hepatology 2009, 50:825-33.

\section{FlOOOPrime}

RECOMMENDED

143. Reiberger T, Ulbrich G, Ferlitsch A, Payer BA, Schwabl P, Pinter M, Heinisch BB, Trauner M, Kramer L, Peck-Radosavljevic M; Vienna Hepatic Hemodynamic Lab: Carvedilol for primary prophylaxis of variceal bleeding in cirrhotic patients with haemodynamic non-response to propranolol. Gut 2013, 62:1634-4I.

\section{FlOOOPrime}

\section{RECOMMENDED}

144. Serste T, Melot C, Francoz C, Durand F, Rautou PE, Valla D, Moreau R, Lebrec D: Deleterious effects of beta-blockers on survival in patients with cirrhosis and refractory ascites. Hepatology 2011, 52:1017-22.

\section{FlOOOPRIM
RECOMMENDED}

145. Krag A, Wiest R, Albillos A, Gluud LL: The window hypothesis: haemodynamic and non-haemodynamic effects of betablockers improve survival of patients with cirrhosis during a window in the disease. Gut 2012, 61:967-9.

146. Mandorfer M, Bota S, Schwabl P, Bucsics T, Pfisterer N, Kruzik M, Hagmann M, Blacky A, Ferlitsch A, Sieghart W, Trauner M, PeckRadosavljevic M, Reiberger T: Nonselective beta Blockers Increase Risk for Hepatorenal Syndrome and Death in Patients With Cirrhosis and Spontaneous Bacterial Peritonitis. Gastroenterology 2014, I46:1680-90. el68I.

147. Stickel F, Hampe ]: Genetic determinants of alcoholic liver disease. Gut 2012, 61:150-9.

148. Nischalke HD, Berger C, Aldenhoff K, Thyssen L, Gentemann M, Grünhage F, Lammert F, Nattermann J, Sauerbruch T, Spengler U, Appenrodt B: Toll-like receptor (TLR) 2 promoter and intron 2 polymorphisms are associated with increased risk for spontaneous bacterial peritonitis in liver cirrhosis. I Hepatol 2011, 55:1010-6.

\section{FlOOOPrime}

\section{RECOMMENDED}

149. Nischalke HD, Berger C, Luda C, Müller T, Berg T, Coenen M, Krämer B, Körner C, Trebicka J, Grünhage F, Lammert F, Nattermann J, Sauerbruch T, Spengler U: The CXCLI rs4074 A allele is associated with enhanced CXCLI responses to TLR2 ligands and predisposes to cirrhosis in HCV genotype I-infected Caucasian patients. J Hepatol 2012, 56:758-64.

150. Nischalke HD, Berger C, Luda C, Berg T, Müller T, Grünhage F, Lammert F, Coenen M, Krämer B, Körner C, Vidovic N, Oldenburg J, Nattermann J, Sauerbruch T, Spengler U: The PNPLA3 rs738409 I 48M/M genotype is a risk factor for liver cancer in alcoholic cirrhosis but shows no or weak association in hepatitis C cirrhosis. PLoS One 201 I, 6:e27087.

15I. Teixeira-Clerc F, Julien B, Grenard P, Tran Van Nhieu J, Deveaux V, Li L, Serriere-Lanneau V, Ledent C, Mallat A, Lotersztajn S: CB I 
cannabinoid receptor antagonism: a new strategy for the treatment of liver fibrosis. Nat Med 2006, I 2:67|-6.

\section{FIOOOPrime}

152. Trebicka J, Racz I, Siegmund SV, Cara E, Granzow M, Schierwagen R, Klein S, Wojtalla A, Hennenberg M, Huss S, Fischer HP, Heller J, Zimmer A, Sauerbruch T: Role of cannabinoid receptors in alcoholic hepatic injury: steatosis and fibrogenesis are increased in $\mathrm{CB}(2)$ receptor-deficient mice and decreased in $\mathbf{C B}(\mathrm{I})$ receptor knockouts. Liver Int 20I I, 3 I:862-72.

153. Huang HC, Wang SS, Hsin IF, Chang CC, Lee FY, Lin HC, Chuang CL, Lee JY, Hsieh HG, Lee SD: Cannabinoid receptor 2 agonist ameliorates mesenteric angiogenesis and portosystemic collaterals in cirrhotic rats. Hepatology 2012, 56:248-58.

154. Steib CJ, Gmelin L, Pfeiler S, Schewe J, Brand S, Goke B, Gerbes AL: Functional relevance of the cannabinoid receptor 2 - heme oxygenase pathway: a novel target for the attenuation of portal hypertension. Life Sci 2013, 93:543-5I.

155. Sahin H, Trautwein C, Wasmuth HE: Functional role of chemokines in liver disease models. Nat Rev Gastroenterol Hepatol 2010, 7:682-90.

156. Fernandez M, Semela D, Bruix J, Colle I, Pinzani M, Bosch J: Angiogenesis in liver disease. J Hepatol 2009, 50:604-20.

157. Mejias M, Garcia-Pras E, Tiani C, Miquel R, Bosch J, Fernandez M: Beneficial effects of sorafenib on splanchnic, intrahepatic, and portocollateral circulations in portal hypertensive and cirrhotic rats. Hepatology 2009, 49:।245-56.

158. Hennenberg M, Trebicka J, Kohistani Z, Stark C, Nischalke HD, Krämer B, Körner C, Klein S, Granzow M, Fischer HP, Heller J, Sauerbruch T: Hepatic and HSC-specific sorafenib effects in rats with established secondary biliary cirrhosis. Lab Invest 2010, $91: 24|-5|$

159. D’Amico M, Mejias M, Garcia-Pras E, Abraldes JG, Garcia-Pagan JC, Fernandez M, Bosch J: Effects of the combined administration of propranolol plus sorafenib on portal hypertension in cirrhotic rats. Am J Physiol Gastrointest Liver Physiol 2012, 302:G I I9I-8.

160. Llovet JM, Ricci S, Mazzaferro V, Hilgard P, Gane E, Blanc JF, de Oliveira AC, Santoro A, Raoul JC, Forner A, Schwartz M, Porta C, Zeuzem S, Bolondi L, Greten TF, Galle PR, Seitz JF, Borbath I, Häussinger D, Giannaris T, Shaun M, Moscovici M, Voliotis D, Bruix J: Sorafenib in advanced hepatocellular carcinoma. $N$ Engl J Med 2008, 359:378-90.

\section{FIOOOPrime \\ RECOMMENDED}

16I. Hennenberg M, Trebicka J, Stark C, Kohistani AZ, Heller J, Sauerbruch T: Sorafenib targets dysregulated Rho kinase expression and portal hypertension in rats with secondary biliary cirrhosis. Br J Pharmacol 2009, 157:258-70.

162. Pinter M, Sieghart W, Reiberger T, Rohr-Udilova N, Ferlitsch A, PeckRadosavljevic $M$ : The effects of sorafenib on the portal hypertensive syndrome in patients with liver cirrhosis and hepatocellular carcinoma-a pilot study. Aliment Pharmacol Ther 2012, 35:83-91.

163. Yovchev MI, Xue Y, Shafritz DA, Locker J, Oertel M: Repopulation of the fibrotic/cirrhotic rat liver by transplanted hepatic stem/progenitor cells and mature hepatocytes. Hepatology 2014, 59:284-95

164. Ricci E, Vanosi G, Lindenmair A, Hennerbichler S, PeterbauerScherb A, Wolbank S, Cargnoni A, Signoroni PB, Campagnol M, Gabriel C, Redl H, Parolini O: Anti-fibrotic effects of fresh and cryopreserved human amniotic membrane in a rat liver fibrosis model. Cell Tissue Bank 2013, I4:475-88.

165. Zheng L, Chu J, Shi Y, Zhou X, Tan L, Li Q, Cui L, Han Z, Han YI, Fan D: Bone marrow-derived stem cells ameliorate hepatic fibrosis by down-regulating interleukin- I 7. Cell Biosci 20I3, 3:46.

166. Desmet VJ: Comments on cirrhosis reversal. Dig Liver Dis 2005, 37:909-16.
167. Lee YA, Friedman SL: Reversal, maintenance or progression: what happens to the liver after a virologic cure of hepatitis C? Antiviral Res 2014, 107:23-30.

168. Muting D, Kalk JF, Fischer R, Wiewel D: Spontaneous regression of oesophageal varices after long-term conservative treatment. Retrospective study in $\mathbf{2 0}$ patients with alcoholic liver cirrhosis, posthepatitic cirrhosis and haemochromatosis with cirrhosis. J Hepatol 1990, 10:158-62.

169. Reynolds TB, Geller HM, Kuzma OT, Redeker AG: Spontaneous decrease in portal pressure with clinical improvement in cirrhosis. $N$ Engl J Med 1960, 263:734-9.

170. Hammel P, Couvelard A, O'Toole D, Ratouis A, Sauvanet A, Fléjou JF, Degott C, Belghiti J, Bernades P, Valla D, Ruszniewski P, Lévy P: Regression of liver fibrosis after biliary drainage in patients with chronic pancreatitis and stenosis of the common bile duct. $N$ Engl J Med 200I, 344:4I8-23.

17I. Dixon JB, Bhathal PS, Hughes NR, O'Brien PE: Nonalcoholic fatty liver disease: Improvement in liver histological analysis with weight loss. Hepatology 2004, 39:1647-54.

172. Falize L, Guillygomarc'h A, Perrin M, Laine F, Guyader D, Brissot P, Turlin B, Deugnier Y: Reversibility of hepatic fibrosis in treated genetic hemochromatosis: a study of 36 cases. Hepatology 2006, 44:472-7

173. Czaja AJ, Carpenter HA: Decreased fibrosis during corticosteroid therapy of autoimmune hepatitis. J Hepatol 2004, 40:646-52.

174. Roberts S, Gordon A, McLean C, Pedersen J, Bowden S, Thomson K, Angus $P$ : Effect of sustained viral response on hepatic venous pressure gradient in hepatitis C-related cirrhosis. Clin Gastroenterol Hepatol 2007, 5:932-7.

175. Manne V, Akhtar E, Saab S: Cirrhosis Regression in Patients With Viral Hepatitis B and C: A Systematic Review. J Clin Gastroenterol 2014, 48:e76-84.

176. Akhtar E, Manne V, Saab S: Cirrhosis regression in hepatitis C patients with sustained virological response after antiviral therapy: a meta-analysis. Liver Int 2014, [Epub ahead of print].

FIOOOPrime
RECOMMENDED

177. Casado JL, Quereda C, Moreno A, Perez-Elias MJ, Marti-Belda P, Moreno S: Regression of liver fibrosis is progressive after sustained virological response to $\mathrm{HCV}$ therapy in patients with hepatitis C and HIV coinfection. J Viral Hepat 2013, 20:829-37.

178. Calvaruso V, Craxi A: Regression of fibrosis after HBV antiviral therapy. Is cirrhosis reversible? Liver Int 20I4, 34(Suppl I):85-90.

179. Poynard T, McHutchison J, Manns M, Trepo C, Lindsay K, Goodman Z, Ling $\mathrm{MH}$, Albrech: Impact of pegylated interferon alfa-2b and ribavirin on liver fibrosis in patients with chronic hepatitis C. Gastroenterology 2002, I22:1303-13.

180. D'Ambrosio R, Aghemo A, Rumi MG, Ronchi G, Donato MF, Paradis V, Colombo M, Bedossa P: A morphometric and immunohistochemical study to assess the benefit of a sustained virological response in hepatitis $\mathbf{C}$ virus patients with cirrhosis. Hepatology 2012, 56:532-43.

\section{FlOOOPrime}

\section{RECOMMENDED}

18I. Issa R, Zhou X, Constandinou CM, Fallowfield J, Millward-Sadler H, Gaca MD, Sands E, Suliman I, Trim N, Knorr A, Arthur MJ, Benyon RC, Iredale JP: Spontaneous recovery from micronodular cirrhosis: evidence for incomplete resolution associated with matrix cross-linking. Gastroenterology 2004, I 26: I795-808.

182. Issa R, Zhou X, Trim N, Millward-Sadler H, Krane S, Benyon C, Iredale J: Mutation in collagen-I that confers resistance to the action of collagenase results in failure of recovery from $\mathrm{CCl} 4$-induced liver fibrosis, persistence of activated hepatic stellate cells, and diminished hepatocyte regeneration. FASEB J 2003, I 7:47-9.

183. Wanless IR, Nakashima E, Sherman M: Regression of human cirrhosis. Morphologic features and the genesis of incomplete septal cirrhosis. Arch Pathol Lab Med 2000, I 24:I599-607. 